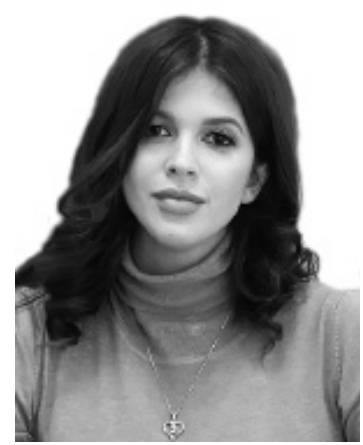

\title{
САМОЗАХИСТ РЕЧОВИХ ПРАВ НА ЧУЖЕ МАЙНО В УКРАÏ̈Н
}

\author{
ФІЛОНОВА Юлія Михайлівна - аспірантка кафедри Цивільного права \\ № 2 Національного юридичного університету ім. Ярослава Мудрого \\ ORCID: https://orcid.org/0000-0001-5250-5455 \\ DOI:10.32782/LAW.2019.3.24
}

В статье дается характеристика понятия самозащить прав на чужое имущество в Украине как неюрисдикционной бормы защить прав. Проведен анализ научной литературь отечественного гражданского законодательства и иностранньх государств. Рассматриваются способъ самозащить прав на чужое имущество и условия их правомерности. В статье бълли проанализированъ существующие теоретико-прикладнъие разработки в сбере самозащить прав в т.ч. прав на чужое имущество, а также разработанъ новъи научнъе предложения для решения поставленной проблемъл. Автор создал теоретическую базу для дальнейшего исследования.

Ключевъе слова: вещнъие права на чужую собственность, самозащита, самозащита вешнъгх прав, признаки бормъ осуществления зашзить гражданских прав.

\section{Вступ}

За сучасних умов розвиток інституту самозахисту в останнє десятиліття актуалізує необхідність у його подальшому дослідженні та науковій систематизації. Слід відзначити, що чинний Цивільний кодекс України не містить статті, яка 6 закріплювала вичерпний перелік способів самозахисту, на відміну від способів захисту цивільних прав судом, закріплених у статті 16 ЦК України, проте оновлення вітчизняного цивільного законодавства треба здійснювати перш за все з урахуванням особливостей національного законодавства. Не викликає сумнівів, що сьогодні в Україні нагальною потребою є суттєва пе- реробка, упорядкування й оновлення правових норм у сфері регламентації цивільних відносин шляхом їх рекодифікації.

Постановка проблеми

У чинному цивільному кодексі України закріплена досить велика кількість способів захисту, зокрема суб'єктивних прав, але виникає питання: чи всі існуючі способи самозахисту можливо застосувати не власникам, тобто особам що мають речові права на чуже майно. Тому існує потреба у проведенні комплексного аналізу чинного законодавства України з метою усунення спірних питань при подальшому практичному застосуванні.

Аналіз останніх досліджень і публікацій

Проблема самозахисту розглядалась багатьма правниками України та інших країн як радянського так і сучасного періодів розвитку цивілістики. Зокрема теоретичні основи цього питання у своїх працях розкривали О. І. Антонюк, В. П. Грибанов, А. В. Венедиктова, Д. М. Генкін, І. О. Дзера, І.В. Жилінкова, О. О. Кот, Н. С. Кузнєцова, І. М. Осолінкєр, Т.М. Підлубна, Г. А. Свердлик, С. А. Страунінг, Р. М. Сидельников, А.І. Скловський, В.А. Яроцький тощо.

Виклад основного матеріалу

У сучасних підручниках із цивільного права під час розгляду категорії «захист цивільних прав» вже традиційно виокремлюється питання про їх «самозахист» [1]. На від- 
міну від європейських країн, у яких еволюція самозахисту проходила під впливом розвитку філософських надбань та ідеї природних прав людини, розвиток інституту самозахисту в Україні відбувався специфічним шляхом, що було пов’язано із відсутністю власної державності. Аише прийняття Цивільного кодексу України у 2003 році, у якому набуло нормативного закріплення поняття «самозахист», стало поштовхом для розвитку та конкретизації наукових досліджень в окресленій сфері. Законодавець обрав шлях загальнодозвільного порядку регулювання. На рівні Конституції України право на самозахист визнається самостійною можливістю учасників цивільних правовідносин на захист свого цивільного права чи інтересу. Перш ніж перейти до аналізу специфіки права на самозахист речових прав на чуже майно, необхідно розглянути сутність загальних положень про самозахист у сучасній цивілістиці. Зокрема, у літературі термін «самозахист цивільних прав» вживається в основному у трьох значеннях: 1) як неюрисдикційна форма захисту цивільних прав, що реалізується через дії зацікавленої особи; 2) як право на самозахист (визначається як елемент правоздатності, правомочність у складі суб'єктивного цивільного права, секундарне право або самостійне цивільне право); 3) як цивільно-правовий інститут. Існують декілька основних поглядів на самозахист. Одним із перших дослідників, який приділяв самозахисту цивільних прав найбільшу увагу, був В. П. Грибанов, який наголосив, що самозахистом 6 здійснення уповноваженою особою дозволених законом дій фактичного порядку, спрямованих на охорону іï особистих майнових прав та інтересів [2]. На думку Г. А. Свердлика та 3. А. Страунінга, самозахист - це передбачені законом або договором дії уповноваженої особи, спрямовані на забезпечення недоторканності права, припинення порушення та ліквідацію наслідків такого порушення.Таким чином, визначення, запропонованіВ. П. Грибановим, Г. А. Свердликом, 3. А. Страунингом, $\epsilon$ протилежними тому, яке закріплено статтею 19 ЦК України. Вказані автори говорять про дії, встановлені законом або договором, натомість, у статті 19 ЦК України міститься посилання виключно про засто- сування засобів протидії, які не заборонені законом [3]. Т. Е. Крисань під самозахистом цивільних прав розуміє дії правомочної особи, що допускаються законом або договором, спрямовані на забезпечення недоторканності права, припинення порушення й ліквідацію його наслідків [4]. Р. Н. Сидельников, не надаючи власного тлумачення, зазначає, що термін «самозахист» $є$ багатозначним й використовується у нормативно-правових актах, а також представниками юридичної науки у різних значеннях [5]. О. І. Антонюк під самозахистом у цивільному праві пропонує розуміти можливість особи в разі порушення iii цивільного права чи інтересу, цивільного права чи інтересу іншої особи або створення реальної загрози такого порушення, застосувати доцільну й адекватну протидію, яка не забороняється законом, не суперечить моральним засадам суспільства та спрямовується на попередження чи припинення цього порушення або ліквідацію його наслідків[6]. I. М. Осолінкер пропонує розглядати самозахист, як правомірну дію, що здійснюється без звернення до компетентних органів держави, спрямовану на застосування проти правопорушника у визначених чинним законодавством України та моральними засадами суспільства межах адекватних змісту порушеного права, характеру правопорушення та його негативним наслідкам, засобів протидії 3 метою відновлення можливості безперешкодного здійснення належного йому чи іншим особам права у випадках його порушення чи реальної загрози порушення [7]. ᄉ. І. Аяшевська визначає самозахист як застосування особою засобів протидії, які не суперечать закону та моральним засадам суспільства [8]. В. Л. Яроцький пояснює велику кількість підходів науковців до трактування поняття «самозахист» вузькою формою викладення положень статті 19 ЦК України й широким їі змістом. На думку науковця, вищевказана стаття лише визначає те, що особа має право на самозахист свого цивільного права та права іншої особи від порушень і протиправних посягань. Самозахистом є застосування особою засобів протидії, які не заборонені законом та не суперечать моральним засадам суспільства. Способи самозахисту мають відповідати змісту права, що пору- 
шене, характеру дій, якими воно порушене, а також наслідками, що спричинені цим порушенням. Способи самозахисту можуть обиратися самою особою чи встановлюватися договором або актами цивільного законодавства [9]. Деякі цивілісти розглядають самозахист як спосіб захисту. Так, ․ ․ Стецюк визначає самозахист як сукупність способів захисту охоронюваних законом прав особи або іншого суб'єкта цивільних правовідносин, що характеризується спільними ознаками та умовами здійснення, й застосовуються за наявності певних підстав особою, яка в даному випадку не здійснюе свої владні функції чи посадові обов'язки [10]. Прихильники визначення самозахисту як способу захисту цивільних прав спираються за аналогією на положення статті 12 Цивільного кодексу Російської Федерації, де самозахист внесено до переліку способів захисту. Таке положення російського законодавства було піддано суттєвій критиці у вітчизняній цивілістиці. Як слушно зауважує В. А. Яроцький [11], самозахист не можна поставити в один ряд iз іншими засобами захисту. Спосіб захисту вказує на те, яким чином той чи інший захід захисту відновлює порушені права, запобігає його порушенню або припиняє таке порушення. Необхідно підтримати точку зору O. I. Антонюк, що право на самозахист має не лише власник речі, але й особа, яка має речове право на чуже майно: право володіння, право користування, право користування земельною ділянкою для сільськогосподарських потреб, право забудови земельної ділянки, право господарського відання та право оперативного управління й інші встановлені законом речові права на чуже майно. Такі особи мають право на самозахист й від неправомірних дій власника майна [12].

Право на самозахист, зокрема й речових прав на чуже майно, як неюрисдикційна форма захисту, сьогодні використовується все частіше. Підтримуючи думку О. О. Кота [13] та В. С. Ковальського [14], що механізм правового регулювання дає змогу глибше пізнати специфіку об'єктів й відносин регулювання, їх спільні та відмінні складові, особливості правового впливу на суспільні відносини, спробуємо розглянути самозахист саме у якості механізму. Відзначимо, що нор- мативно врегульовані не всі можливі способи реалізації вказаної форми, й безпосередній механізм самозахисту сформований досить узагальнено та спрощено. Відтак, постає необхідність розгляду механізму самозахисту, зокрема й речових прав на чуже майно. Такої правової категорії, як «механізм самозахисту», чинним законодавством України не передбачено. На необхідність легалізованого закріплення вказаного механізму наголошує I. М. Осолінкєр, обгрунтовуючи це тим, що засоби юрисдикційного захисту не завжди можуть вчасно нейтралізувати правопорушення й відновити право власності особи [7, с.192]. На думку С. С. Алексєєва, поняття механізму правового регулювання надає можливість не тільки зібрати разом явища правової дійсності - норми, правовідносини, юридичні акти та інше, а й визначити їх як цілісність та уявити їх у «працюючому», системно-динамічному вигляді, який характеризує результативність правового регулювання, його здатність гарантувати 3 правового боку досягнення цілей, поставлених законодавцем; висвітлити у зв'язку із цим специфічні функції, які виконують ті чи інші правові явища у правовій системі, продемонструвати їх зв'язок між собою та взаємодію [15,с.10]. 3 урахуванням окресленого погляду, науковець виділяє три ланки (елементи) механізму правового регулювання: юридичні норми (як основу), правовідносини, акти реалізації прав і обов'язків[16, с. 216]. Як слушно наголошує Н. С. Кузнєцова, науковцями було запропоновано значну кількість визначень поняття механізму правового регулювання, однак вони в цілому залишаються у межах загального розуміння дефініції С. С. Алексєєва, яка була сприйнята й у сучасній вітчизняній цивілістиці [17, с.32]. Аналогічний висновок було висловлено й О. О. Котом, який, дослідивши існуючі пропозиції щодо визначення механізму регулювання, наголошує, що більш послідовними є погляди С. С. Алексєєва на стадії та елементи механізму правового регулювання, оскільки вони найбільш точно відображають ключові етапи реалізації об'єктивного права в суспільному житті [13,с.205]. В. А. Яроцький розглядає зазначене питання з точки зору універсальності регламентованого впливу механізму цивільно- 
правового регулювання на приватноправові відносини, як певний алгоритм, що визначається у словнику як «сукупність дій (динаміка) і правил (статика) для вирішення завдання (результат)» [9]. М.М. Мальцев пропонує визначити механізм самозахисту прав як сукупність підстав і умов правомірності самозахисту прав, способів та форм його реалізації [18]. Натомість, К. Б. Живіхина висловила іншу точку зору, відповідно до якої механізм правового регулювання - це комплексна система юридичних засобів, яка включає до себе юридичні норми, правовідносини й акти реалізації прав та обов'язків суб'єктів, у тому числі правозастосовчу діяльність, що не відповідає категорії «захист права власності» та самостійних правовідносин. Відтак, під час здійснення захисту права власності не виникає. Найбільш доречно визнавати існування механізму правового регулювання правовідносин власності, у рамках якого реалізується ïх захист [19, с. 23-24]. Д. В. Микшис у своєму дослідженні приходить до протилежних висновків. По-перше, науковець не погоджується $з$ тими дослідниками, які застосовують до сфери захисту прав розгорнуту структуру механізму правового регулювання без урахування особливостей процесу захисту прав, зауважуючи, що такий підхід є неповним й не відображає сутності механізму самозахисту. Самозахист цивільних прав має власний механізм реалізації, який відрізняється за своєю структурою від механізму правового регулювання. 3 функціональної точки зору, зайвими виступають такі елементи, як порушення права, охоронне правовідношення й реальне усунення порушень права, які представляють собою, відповідно, передумову, форму й результат дії механізму захисту прав. По-друге, на думку правника, механізм захисту прав складається 3 двох елементів: засобів (статичний елемент) захисту і способів (динамічний елемент) захисту [20]. 3 урахуванням викладеного вище можна зробити висновок, що для визначення такої категорії, як механізм самозахисту, необхідно визначити складові елементи відповідного механізму з урахуванням особливостей процесу самозахисту.

Підставою для застосування самозахисту у загальному розумінні вважають пору- шення суб'єктивного права, яке вже розпочалось. Так, більшість науковців вважає, що самозахист є реакцією на протиправні дії протилежної сторони. Водночас, Ч. Н. Азімов [21,с.137], В. М. Баранов [22, с.92],В. П. Смельянов [23,с.14-15] та інші підкрес^юють, що порушення мають бути реальними, наявними й вже розпочатими. Такі дослідники як М. С. Корабльова [23, с.88],Т. М. Підлубна [25], С. П. Параниця [26,с.34], Н. П. Боднар [27,с.138] та інші вважають, що підставою застосування самозахисту є не лише порушення права, а й реальна загроза такого порушення.

На думку М. I. Архіпової, способи самозахисту речових прав слід класифікувати за такими критеріями: 1) залежно від форми закріплення можливостей реалізації того або іншого способу самозахисту: встановлені актами цивільного законодавства (необхідна оборона, крайня необхідність); встановлені договором (майнове страхування, укладення договору зберігання); обрані самою особою (встановлення огорожі); 2) залежно від суб'єкта, що реалізує право на самозахист: ті, що здійснюються самостійно правомочною особою; ті, що здійснюються третьою особою як за дорученням, так і без нього;3) залежно від юридичної природи способу самозахисту: міри захисту (необхідна оборона, крайня необхідність); міри відповідальності (відшкодування збитків). Слід погодитися 3 I. М. Осолінкером, що така класифікація є невичерпною й не розкриває всіх властивостей самозахисту права власності. Значно ширшу за обсягом класифікацію на-

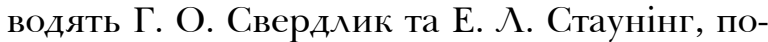
силаючись на те, що основою розмежування може стати будь-яка властивість залежно від характеру й природи наявних відмінностей. Така класифікація має не тільки теоретична, й прикладне значення, оскільки дозволяє учасникам цивільного обороту достатньо легко орієнтуватися у виборі способів самозахисту й визначенні їх меж, що, у свою чергу, надає можливість захистити цивільні права особам, які ними володіють, швидко й повною мірою [7,с.117]. М. С. Корабльова способи самозахисту поділяє на фактичні («силові») й юридичні («несилові»). До фактичних способів пропонується відносити дії, вчинені 


\section{Цивільне, підприємницьке, господарське та трудове право}

у стані необхідної оборони і крайньої необхідності, а до юридичних - заходи оперативного впливу й утримання [24]. Д. В. Микшис пропонує розділяти способи самозахисту за функціональним критерієм на чотири групи: пресічні, відновлювальні, забезпечувальні та компенсаційні. Системоутворюючим критерієм для такої класифікації є динаміка розвитку правопорушення, що по черзі викликає до життя основні функції самозахисту [20]. Способи самозахисту цивільних прав - це дія або система дій, направлених на захист цивільних прав, що застосовується уповноваженими на те законом або договором особами без звернення до відповідних державних або інших правоохоронних органів [26, с.7].B. $\mathcal{~}$. Яроцький визначає спосіб захисту чи самозахисту речових прав як вольове діяння (дію або бездіяльність), що відповідає меті ліквідації загрози порушення речових прав або його відновлення, й визначається як таке діяння, що відповідає на питання: яким чином здійснюється захист і самозахист речових прав? [15,с.168]. Погоджуючись 3 останньою наведеною дефініцією, можна констатувати, що способи самозахисту речових прав на чуже майно - це вольове діяння (дія або бездіяльність), що відповідає меті ліквідації загрози порушення речових прав на чуже майно або їх відновлення й визначає порядок реалізації самозахисту речових прав на чуже майно. У свою чергу, засіб самозахисту речових прав на чуже майно - це дії, спрямовані на досягнення конкретного результату й відповідають на питання: що саме може суб'єкт захисту вимагати в даному випадку в конкретній ситуації?

Для визначення способів самозахисту речових прав на чуже майно звернемося до досвіду зарубіжних країн. Достатньо розвинений інститут самозахисту в Німеччині. Система способів самозахисту, встановлена в німецькому законодавстві, слугує моделлю не тільки для країн Західної Европи,а й для деяких держав на пострадянському просторі. Діюча в німецькому праві система способів самозахисту включає в себе: дії в стані необхідної оборони (§ 227 НЦУ); дії в стані крайньої необхідності (§ 228 НЦУ), такі як вплив на річ, що належить іншій особі, якщо такий вплив необхідний для запобігання наявної небезпеки i передбачувана шкода істотно перевищує шкоду, завдану власнику внаслідок впливу на річ (§ 904 НЦУ); право власника бджолиного рою проникати на сусідні ділянки для його переслідування і відкрити чужий вулик і вийняти або виламати стільники, з відшкодуванням завданих збитків (§ 962 НЦУ); самодопомогу (§ 229-231 НЦУ), а саме: право наймодавця на самодопомогу в захисті свого заставного права, яке виражається в наступному: якщо наймодавцю належить право заперечувати проти видалення речей, на які він має заставне право, то наймодавець має право, не звертаючись до суду, своїми діями перешкодити видаленню речей. У § 229 НЦУ встановлено, що з метою самодопомоги уповноважений має право вилучати, знищувати або пошкоджувати якунебудь річ, затримувати особу, запідозрену в бажанні зникнути, долати опір тощо, тобто визначаються міри самозахисту. У разі, коли наймач залишає предмет найму, наймодавець може залишити вищевказані речі у себе (§ 559 і абзац 1 § 561 НЦУ); таким же правом володіє власник готелю щодо речей постояльця (§ 704 НЦУ); затримання боржника для встановлення його особи; самодопомога власника (згідно з 859 НЦУ, власник може силою опиратися забороненого самоуправству, а в разі, якщо рухома річ буде відібрано від власника шляхом забороненого самоуправства, він може силою забрати ії у особи, яка вчинила самоуправство, в тому випадку, коли порушник був застигнутий на місці або виявлений по свіжих слідах); самодопомога інших осіб від імені власника (§ 860 НЦУ); самостійне усунення сусідського незручності, передбачене § 910 НЦУ (право власника земельної ділянки обрізати коріння дерева або куща або висячі гілки, які проникли до нього $з$ сусідньої земельної ділянки); самостійне вилучення орендарем відокремлених поліпшень орендованої речі (вилучення пристрою, яким він обладнав річ), передбачене $\S$ 591 НЦу [27]. Необхідно звернути особливу увагу, що відповідно §859 НЦУ в залежності від того, яка річ є об'єктом самоуправства рухома або нерухома, вказує два способи самозахисту саме фактичного володіння: якщо необхідно захистити володіння рухомою річчю - відбирання речі силою у порушни- 
ка; якщо необхідно захистити володіння нерухомої річчю - видалення порушника із земельної ділянки. Правове регулювання самозахисту прав за чинним цивільним законодавством України засновано на принципі «дозволено все, що не заборонено». У зв’язку 3 таким підходом законодавця встановлення вичерпного переліку способів самозахисту, з одного боку, суперечило 6 диспозитивному принципу регулювання відносин самозахисту. Згідно з частиною 1 статті 19 ЦК України самозахистом є застосування особою засобів протидії, які не заборонені законом і не суперечать моральним засадам суспільства. Вимоги вказаної статті щодо правомірності дій під час самозахисту уточнюються у їі другій частині, відповідно до якої способи самозахисту мають відповідати змісту права, що порушене, характеру дій, якими воно порушене, а також наслідкам, що завдані цим порушенням. Водночас німецький законодавець обрав досить правильний підхід до розуміння самозахисту, закріпивши достатньо розгорнутий вичерпний перелік можливих способів самозахисту, що, вважаємо, може бути позитивно сприйнято і вітчизняним цивільним законодавством.

\section{Висновок}

Таким чином, самозахист речових прав на чуже майно - це неюрисдикційна форма захисту управоможеною особою, що виражається в самостійних діях, які не заборонені законом і не суперечать моральним засадам суспільства, спрямовані на припинення порушення або відновлення порушеного права або усунення реальної загрози виникнення такого порушення. Засоби самозахисту повинні обмежуватися негайними й пропорційними заходами, необхідними та достатніми для повернення речі, припинення або запобігання позбавлення володіння, або його порушення, а також для видалення правопорушника з території нерухомої речі.У залежності від способу порушення речових прав на чуже майно (позбавлення володіння, пошкодження або знищення об'єкта цих прав, неправомірне користування об'єктами чи неправомірне, створення перешкод щодо користування) самозахист речових прав на чуже майно може бути спрямований: 1) на усунення перешкод щодо користування речовими правами на чуже майно; 2) на відновлення порушених речових прав на чуже майно.

Враховуючи проаналізовані підходи, вбачається за можливе запропонувати узагальнену дефініцію поняття механізму самозахисту речових прав на чуже майно, під яким необхідно розуміти сукупність чітко структурованих й функціонально визначених елементів, які існують у межах динаміки суспільних правовідносин у процесі їх реалізації. Відтак, вказана правова категорія розкриває підстави для застосування самозахисту речових прав на чуже майно, визначає умови, межі застосування, також визначає способи й засоби, за допомогою яких можливо самостійно здійснювати захист суб'єктивних прав і охоронюваних законом інтересів.

\section{入iтература}

1. Сидельников Р. Ознаки самозахисту цивільних прав. Вісник Академї правових наук Украӥни. 2004. No 2 (37). С. 214-222.

2. Грибанов В.П. Осуществление и защита гражданских прав/ 2-е изд., стереотип. М.: Статут, 2001. 411 с.

3. Свердлик Г. А. Защита и самозащита гражданских прав : учебное пособие. М.: Лекс-Книга, 2002. 208 с.

4. Крисань Т. Форми реалізації юридичних гарантій цивільних прав. Закон и жизнь. 2013. № 1. С. 24-27.

5. Сидельников Р.Н Право на самозахист у Сімейному кодексі України.Проблеми законності : Респ. міжвідом. наук. зб. Відп. ред. В.Я. Тацій. Харків: Нац. юрид. акад. України, 2003. Вип. 63. 145 с.

6. Антонюк O.I. Право учасників цивільних правовідносин на самозахист : дис. . канд. юрид. наук : спец. 12.00.03 .Х., 2004. 205 c.

7. Осолінкер I. М. Самозахист права власності в Україні : дис. канд. юрид. наук : 12.00.03. Х. 2011. 217 с.

8. Ляшевська ᄉ.I. Підстави та умови виникнення відповідальності за заподіяння шкоди, завданої особою у разі здійснення самозахисту. Вісник Харківського національного університету імені В. Н. Каразіна. 2014.№ 1106, вип. 17. С. 235-240. (Серія: Право). 
9. Яроцький В.Л. Характеристика самозахисту речових прав як різновиду правомірних дій .Форум права. 2013. №4.

10. Стецюк $\lambda$. $\lambda$. Самозахист як форма захисту цивільних прав. Університетсъкі наук. записки. 2008. No 3 (27). С. $151-158$.

11. В. А. Яроцький Самозахист як правовий засіб захисту речових прав. Вісник Наиіонального університету «Юридична академія Украйни імені Ярослава Мудрого. Сер.: Економічна теорія та право. 2014. № 1. С. 160-170. Peжим доступу: http://nbuv.gov.ua/UJRN/Vnyua_ etp_2014_1_18.

12. Антонюк O. I. Право учасників цивільних правовідносин на самозахист : дис. канд. юрид. наук : 12.00.03. Х., 2004. 205 с.

13. Кот О. О. Проблеми здійснення та захисту суб'єктивних цивільних прав: автореф. дис. ... д-ра юрид. наук : 12.00.03. Київ: Наук.-досл. ін.-т прив. права і підпр-ва ім. академіка Ф.Г.Бурчака, 2017.

14. Ковальський В. С. Охоронна функція К. : Юрінком Інтер, 2010. 336 с.

15. Алексеев С. С. Общая теория права: в 2 т. М.: Юрид. лит. 1982. 360 с.

16. Алексеев С. С. Теория права : в 2 т.T. II.M.: БЕК., 1995. 320 c.

17. Кузнецова Н. С. Гражданско-правовая ответственность: понятие, условия и механизм применения. Альманах иивилистики: сб.ст.; вып. 3 под ред. Р. А. Майданика. К.: Алерта : КНТ : Центр учеб. лит. 2010. С. 3048.

18. Мальцев М.Н. Самозащита субъективных прав по российскому законодательству (теоретико-правовое исследование): автореф. дис... канд. юр. наук. Саратов, 2006. 24 c.

19. Живихина К. Б. Гражданско-правовые проблемы охраны и защиты права собственности: дис...д-ра юрид. наук. М., 2006.

20. Микшис Д.В. Самозащита в гражданском праве России: дис. ... канд. юрид. наук. Екатеринбург, 2006

21. Азімов Ч. Здійснення самозахисту в цивільному праві.Вісн. Акад. прав. наук. України. 2001. № 2 (25). С. 135 - 141.

22. Баранов В. М. Гражданская самозащита в правозащитной системе государства. Сочиология и право. 2011. № 1(7). С. 86 - 102.
23 Емельянов В. Пределы осуществления гражданских прав.Рос. юстииия. 1999. № 6. C. $14-15$.

24. Кораблева М. С. Защита гражданских прав: новые аспекты. Актуальные вопросъ гражданского права. под ред. М. М. Брагинского. М.: Статут, 1998. С. $76-108$.

25. Підлубна Т. М. Право на захист цивільних прав та інтересів. Чернівці: Чернів. нац. ун-т, 2010. 128 с.

26. Параниця С. П. Самозахист як самостійне суб'єктивне право особи Часопис Київ. ун-ту права. 2011. № 2. С. 33 - 36.

27. Боднар Н. П. Історія становлення та розвитку інституту превентивного захисту цивільних прав. Biсн. госп. судочинства. 2010. № 3. C. $133-139$.

28. Эннекцерус $\Lambda$. Курс германского гражданского права. Т. 1. Полутом 2. М., 1950.

\section{Self-defense of rights in rem to another's property in Ukraine}

Abstract. The Institute of Self-Defense

arose at an early stage of human society development as the first and most widespread form of defense.

In modern conditions the development of the Institute of self-defense in the last decade effectuate the need for further research and scientific systematization. It should be noted that the current Civil Code of Ukraine does not contain any article that would provide an exhaustive list of ways of self-defense, in contrast to the ways of defence of civil rights by the court enshrined in Article 16 of the Civil Code of Ukraine. But first of all the updating of the domestic civil legislation should be carried out by taking into account the peculiarities of national legislation.

There is no doubt that nowadays in Ukraine there is an urgent need to substantially revise, streamline and update legal norms in the field of regulation of civil relations through their recodification. In this context, it is not only the current mechanism of self-defense that needs to be specified in the context of the positive foreign experience of continental Europe. The right to self-defense, including the right in rem 


\begin{tabular}{|c|}
\hline $\begin{array}{l}\text { Устатті дається характеристика понят- } \\
\text { тя самозахисту речових прав на чуже майно } \\
\text { в Украйні як неюрисдикиійной фороми захисту } \\
\text { прав. Проведено аналіз наукової літератури ві- } \\
\text { тчизняного иивільного законодавства та іно- } \\
\text { земних держав. Розглядаються способи само- } \\
\text { захисту речових прав на чуже майно та умови } \\
\text { ихх правомірності. У статті було проаналізо- } \\
\text { вано існуючі теоретико-прикладні розробки в } \\
\text { сфері самозахисту речових прав, у т.ч. речових } \\
\text { прав на чуже майно, а також розроблені нові } \\
\text { наукові пропозииї для вирішення поставленої } \\
\text { проблеми. Автор заклав теоретичну базу для } \\
\text { подальшого дослідження. } \\
\text { Ключові слова: речові права на чуже май- } \\
\text { но, самозахист, ознаки самозахисту, борми } \\
\text { здіиснення захисту иивільних прав.' }\end{array}$ \\
\hline
\end{tabular}

to another's property as a non-jurisdictional form of protection is increasingly used today. It should be noted that not all possible ways of selfdefense are regulated, and the mechanism of self-defense is quite generalized and simplified. Therefore, there is a need to consider the mechanism of self-defense, including the rights in rem to another's property.

The purpose of the article is to conduct a comprehensive analysis of the Institute of selfdefense and the mechanism of its operation. The current Civil Code of Ukraine enshrines a large number of ways to defend the rights, including subjective rights. But the question arises: whether all existing methods of self-defense can be applied by a person, who is not the proprietor, that is, by persons who have rights in rem to someone else's property. Therefore, there is a need to carry out a comprehensive analysis of the current legislation of Ukraine in order to eliminate controversial issues in the future practical application.

It is shown that the legal regulation of selfdefense rights according to the current civil law of Ukraine is based on the «everything is allowed that is not forbidden» principle.
The determination of a complete list of selfdefense methods might be controversial to the dispositiveness of self-defense relations regulation. Self-defense is defined as the use of counter-measures by a person, which are not prohibited by the law and do not contradict to the moral principles of society according to the part 1 of Article 19 of the Civil Code of Ukraine. The requirements of the above-mentioned Article concerning the lawfulness of the actions during the self-defense are specified in its second part, according to which, the methods of self-defense should correspond to the violated purview content, nature of offence, and the consequences caused by this violation. It is found out that the German legislator choose a more faithful approach to the self-defense understanding by setting out a sufficiently detailed list of potential self-defense methods that can be favorably perceived by domestic civil law.

It is shown that depending on the method of violating the rights in rem to other's property (deprivation of ownership, damage or destruction of the object of these rights, misuse of objects or unlawful obstruction of use) self-defense of rights in rem to other's property can be aimed at: 1) eliminating obstacles to the use of rights in rem to other's property; 2) restoring of violated rights in rem to other's property. It is shown that self-defense of rights in rem to other's property is a non-jurisdictional form of protection of an authorized person, which is expressed in independent actions not prohibited by law and that do not contravene the moral principles of society, aimed at terminating the violation or restoring the violated right or eliminating such a threat. Self-defense must be limited by immediate and proportionate measures, that are necessary and sufficient to return the property, suspend or prevent deprivation of property, its destruction or removal of the offender from the territory of real estate.

Key words: real rights in another's property, self-defense, self-defense, forms of civil rights protection. 